\title{
Ekrem Reşid Rey ve Cemal Reşid Rey Operalarr*
}

\author{
Elif Sanem Güleç* \\ İbrahim Şevket Güleç**
}

$\ddot{0} z$

Ekrem Reşid Rey (10 Ekim 1900-13 Temmuz 1959) ve Cemal Reşid Rey'in (25 Ekim 1904-7 Ekim 1985) yaşamı, Osmanlı'dan Cumhuriyet'e geçişin simgesidir. Türk Beşleri diye adlandırılan besteciler kuşağının ilk temsilcisi olan Cemal Reşid Rey'in, sahne yapıtlarını üretirken en büyük paydaşı kardeşi Ekrem Reşid Rey olmuştur. Osmanlı İmparatorluğu’nda kent kültürü içinde yaşayan operetin, Cumhuriyet dönemi halkasını Rey kardeşler oluşturur. Büyük beğeni kazanan bu operetler sahnede yer bulurken, operalar gündeme gelmemiştir. Literatürde bu eserler hakkında sınırlı sayıda bilgi mevcuttur. Makalede; Ekrem Reşid Rey ve Cemal Reşid Rey'in La Femme Fugitive (Kaçan Kadın), Faire Sans Dire (Söylemeden Yapmak), Sultan Cem, L'Enchantement (Büyülenme), Zeibek (Zeybek), Drame Anatolien (Köyde Bir Facia) ve Çelebi adlı yedi operası ele alınmıştır. Çalışma, Türk opera literatürüne ve Devlet Opera ve Balesi arşivine katkı sağlamayı amaçlamaktadır.

\section{Anahtar Kelimeler}

Ekrem Reşid Rey, Cemal Reşid Rey, Osmanlı İmparatorluğu, Cumhuriyet dönemi, opera, operet.

\footnotetext{
* Geliş Tarihi: 12 Ağustos 2016 - Kabul Tarihi: 14 Mart 2017

Bu makaleyi şu şekilde kaynak gösterebilirsiniz:

Güleç, Elif Sanem ve İbrahim Şevket Güleç (2020). "Ekrem Reşid Rey ve Cemal Reşid Rey

Operaları”. bilig - Türk Dünyası Sosyal Bilimler Dergisi 93: 53-84.

“ Dr. Öğretim Üyesi, Kocaeli Üniversitesi, Güzel Sanatlar Fakültesi, Müzik Bölümü - İzmit/Kocaeli ORCID ID: 0000-0002-9288-3255

elifsanem@gmail.com

'“'Arş. Gör., Necmetttin Erbakan Üniversitesi, Türk Müziği Devlet Konservatuvarı, Müzik Bölümü Meram/Konya ORCID ID: 0000-0002-7961-5715

isg7734@gmail.com
} 


\section{Giriş}

Cemal Reşid Rey'in 1932 yılından başlayarak müzik üretiminde, operet geleneğine yönelmesinin en önemli nedeni; "Batı müzik kültürüne ait olan operet türünün 19. yüzyılın ikinci yarısından başlayarak Osmanlı kültürü tarafından benimsenmiş" olmasıdır (Uçarsu 2004: 78).

Osmanlı İmparatorluğu'nda operanın gelişimi ve asıl temsiliyeti, padişahın izni ve maddi desteği ile açılan özel tiyatrolar çerçevesinde olmuştur. Önceleri tiyatro ve operaya zengin levantenler, padişah ve çevresi giderken, Naum Tiyatrosunun ardından ulusal operetlerin sahnelendiği tiyatroların ortaya çıkışıyla sanat alanındaki kültürleşme halka yayılmaya başlar.

Operet; İstanbul kent kültüründe zaman içinde ortaoyunu, tuluat tiyatrosu gibi geleneksel sahne sanatlarının etkileriyle yerli bir kimlik kazanıp benimsenir.

Ekrem Reşid Rey ve Cemal Reşid Rey, geçmişi ve geleneği olan bu türün Cumhuriyet dönemi halkasını oluştururlar. "Bu tamamen akılcı, uygulamaya dönük ve etkili bir yaklaşımdır. Sahne eserlerinin kitle tarafından büyük beğeniyle karşılanması ve benimsenmesi, bestecinin estetik görüşlerinin keskinliğini doğrular niteliktedir” (Uçarsu 2004: 78).

Cemal Reşid Rey, Murat Tuncay'la (2010: 44-45) yaptığı söyleşide bu konudaki düşüncelerini şöyle dile getirmektedir:

M.T: Peki, Türk temaşa sanatları içinde Cumhuriyet dönemi müzikli oyunlarının taşıdıkları yenilikler nelerdi sizce?

C.R.R: Aslında operet geleneği bizde eskidir. Cemal Sahir Kumpanyası vardı. Eskiden beri bu türden eserler oynanırdı. Dikran Çuhacıyan'ın müzikli tiyatrosu vardı mesela. Ama o zamanların operet müzikleri biraz incesaz çerçevesinde kalmıştır. Her ne kadar Çuhacıyan'da olduğu gibi bazı armonik şeyler görülse de İncesaz’’n ağırlığı kendisini belli eder.

Birinci Dünya Savaşı sırasında Avrupa’daydım. Viyana Opereti İstanbul'a gelmiş Czardaş, Kontes Mariça oynamış. Bu oyunların tesiri olmuş. Bizde de adaptasyonları (uyarlamaları) çıkmıs. Fakat alaturka ile alafranga arası bir şeyler. İşte ancak $\ddot{U}_{c ̧} S a a t$ ten itibaren doğrudan doğruya Batı tekniği ile yapılmış bir oyun ve müzik karşısında bulunuyoruz. 
M.T: İzninizle sözü operetlere getirmek istiyorum. Bu devirde oynanan oyunlar arasında operetlerin yeri sizce ne olmuştur?

C.R.R: Operetler Şehir Tiyatrosunun altın devridir. Bizde tarihe geçebilecek kudrete erişebilen ilk operet $\ddot{U}_{\mathcal{G}}$ Saat'dir. Oynandığ ilk mevsimde ya yetmiş ya da seksen kere sahnelendi. O zamanlar en babayiğit oyun bir haftadan fazla oynanamazdı. Bazen haftada sadece iki oyun oynanabilirdi. Seyirci o kadar azdı. Ü̧̧ Saat opereti müziği ile oyunun mizanseniyle, balesiyle neşesiyle, herşeyiyle halkın arzusuna, iştiyakına (özlemle beklediklerine) cevap veriyordu. Halk akın akın tiyatroya geldi. Bunun üzerine bu işin peşini bırakmadık. Bırakılamazdı zaten. Ertesi yıl Cumhuriyet'in onuncu yılında Lüküs Hayat operetini verdik. O daha da büyük başarı kazandı. Sonra sırasıyla Delidolu, Saz Caz, Maskara oynandı....

M.T: O devir bestecileri arasında operet yolu ile halkın çok sesli müzik alanında eğitilmesi görüşü ağırlıkta mıydı? Siz ilk operetlerinizde böyle bir düşünce güttünüz mü?

C.R.R: Elbette. Bir insanı cezbetmek (kendine çekmek) için o insana tebessüm etmek icap eder (gülümsemek gerekir). Operet bir tebessümdür. Operalar, güç anlaşılır, senfoniler halkı kolay cezbetmez. Bunu bilerek, isteyerek yaptık.

Sanatçıların sağladıkları bu başarının nedeni; “operet geleneğinin kent insanının geçmişinde, gazel, taksim gibi kökleşmiş değerlerinden beslenmiş olması ve bu değerler üzerinde temellenerek kitleyle kalıcı iletişim zemini kurmaya olanak vermesidir" (Uçarsu 2004: 78).

Ekrem Reşid ve Cemal Reşid Rey’in bugüne kadar halen sahnelenmemiş, çalışmaya konu olan yedi operası incelenirken; yazılış tarihi, libretto yazarı, ilk temsil tarihi, rol dağılımı, orkestra ve konu özeti başlıkları takip edilmiştir.

Bu eserlerin dışında; Cemal Reşid ve Ekrem Reşid'e ait “Balkis Reine de Saba” adlı (Bozok 1950:12) (Saba Melikesi Belkıs, 1930, Binbir Gece Masalları'nı Fransızcaya nakleden Mardrus'ten adapte, opera 4 tablo)" yeni bir operaya rastlanmıştır. Ancak eserle ilgili bilgiye ulaşılamamıştır.

Cemal Reşid Rey’in, librettosu Ekrem Reşid'e ait olmayan operaları da vardır. Bunlardan birincisi; 1920 yılında bestelediği librettosu Xavier 
Fromentin'e ait Jann Marek'tir. İkincisi; Cumhuriyet gazetesinin 19 Haziran 1964 (s. 1 ve s.7) tarihli yazısından öğrendiğimiz, bestecinin Atatürk Kültür Merkezinin açılışı için hazırladığı, librettosu Nazım Kurşunlu’ya ait Fatih operasıdır. Ancak bu operanın da hangi sebepten ötürü tamamlanamadığı bilinmemektedir. Bestecinin eser kataloğunda opera olarak adlandırılan $L a$ Geisha’nın, Cemal Reşid'in mirasçısı Osman Ergün'den temin edilen orijinal partisyonda bestecinin el yazısından (Operette en 2 Acte de Sdyney Jones) operet olduğu anlaşılmaktadır.

\section{Ekrem Reşid Rey ve Cemal Reşid Rey}

Ekrem Reşid ve Cemal Reşid'in babası Ahmet Reşid Bey (1870-1956) 29 Ekim 1912'de kurulan Kâmil Paşa Kabinesinde dâhiliye nazırıdır. İttihatçılarla iyi geçinemediği için yurt dışına gitmek zorunda kalır (Polat 2003:16). 1913'te aile memleketi terk eder. Rey kardeşler eğitimlerini yurt dışında tamamlar.

Ekrem Reşid Rey Galatasay Sultanisinde, Paris'te Lycée Buffonda, Cenevre Üniversitesinde okur. Cenevre Güzel Sanatlar Akademisini birincilikle bitirir. "1919 sonlarında yurda döner. Ankara (1938-1940) ve İstanbul (1950-1955) radyolarında temsil kolu şefi olarak çalışır. İstanbul Edebiyat Fakültesinde, Teknik Üniversitede Fransızca okutmanlığı yapar" (Necatigil 2000: 319-320).

Cemal Reşid öğrenimine Paris'te Lycée Buffonda devam eder, ünlü piyano pedagogu Marguerite Long'un öğrencisi olur. Birinci Dünya Savaşı'nın başlamasıyla aile Cenevre'ye geçince Cemal Reşid de eğitimini oradaki St. Antoine Kolejinde ve Cenevre Konservatuarında sürdürür. 1920'de Paris'e dönerek yine Marguerite Long'un (1874-1966) piyano kurslarına katılır, Raoul Laparra'dan (1876-1943) kompozisyon dersleri alır; ayrıca Gabriel Fauré (1845-1924) ile müzik estetiği ve Henri Defosse (1883-1956) ile orkestra şefliği çalışır.

Cemal Reşid Rey 1923'te, Cumhuriyet'in kurulmasıyla Dârülelhanda kompozisyon ve piyano dersleri vermek üzere yurda döner. 1926 yilında konservatuarda çoksesli bir koro kuran sanatçı, 1934'te bir yaylı sazlar grubu oluşturur. "1945-46 yıllarında üfleme çalgıların da eklenmesiyle bir senfonik orkestra özelliğine kavuşan bu topluluk bugünkü İstanbul Devlet Senfoni Orkestrasının temeli olur” (İlyasoğlu 2007: 23-24). 
"Ekrem Reşid Rey bir tiyatro yazarı olarak Türk seyircisinin karşısına kardeşi Cemal Reşid Rey'le birlikte hazırladıkları Üç Saat adlı bir revü operetle çıkar (1932)" (Ali 1996: 42). Ekrem Reşid Rey'in tiyatro alanındaki ününün yayılmasında, İstanbul ve Ankara Radyosunda piyes yazarı ve rejisör olarak yaptığı çalışmaların katkısı büyüktür. 1938-40 yılları arasında Ankara Radyosunda temsil kolu şefliği yaptığı dönemde, İstanbul Şehir Tiyatrosundan seçtiği bazı sanatçıları Ankara’ya götürür. Türkiye'deki radyo temsillerinin temellerini atarak, kısa bir zamanda oldukça zengin bir repertuar oluşturur. 1950-55 yılları arasında İstanbul Radyosunda görev yapar. 1940'dan itibaren Son Posta, Hakikat, Akşam ve Tercüman gazetelerinde tiyatro hakkında yazılar yazar (Bozok 1950).

Ekrem Reşid Rey Fransızca romanlar da yazmış ve onları Fransảda yayımlatmışır. Bunlardan bazıları: Le Turban Dénoué, Melek, Désorientée, Les Glaces Déformantes gibi başlıklar taşır. Türkçe ve Fransızca olarak yazdığı Barbaros Hayreddin'in Hayatı adlı kitap (La Vie de Khaireddine Barberousse) sekiz dile çevrilir. "Bu yapıtı ona Fransız Yazarlar Cemiyeti üyeliğini getirir. Ekrem Reşid Rey Fransız Hükümetinden bu romanı nedeniyle Officier d'Academie rütbesini alır" (Necatigil 2000: 319-320).

Cemal Reşid Rey'in 1915'den 1925'e kadar ürettiği eserler postromantik ve izlenimci etkiler taşır. La Femme Fugitive (Kaçan Kadın) (1917 veya 1918), Faire Sans Dire (1920), Jann Marek (1920), Sultan Cem (1923) ve L'Enchantement (Büyülenme) (1925) bu döneme ait ilk denemeleridir. 1926'dan sonra Türk folkloru ve makam müziğimizden esinlenir. Zeibek (Zeybek) ve Drame Anatolien (Köyde Bir Facia) bu döneme ait eserlerdir. Besteci, Avrupa'nın gündemindeki postromantizmin etkisiyle programlı müzik örnekleri vererek, "müzikle bir olayı betimleme sanatını Türk müziğinde ilk sunan besteci” (İlyasoğlu 2005:120) olur. Programlı müzik alanında verdiği eserlerden Bebek Senfonik Şiiri (La Légende du Bebek-1928) Désiré E. Inghelbrecht yönetiminde Pasdeloup Orkestrası tarafindan Paris'in Théatre des Champs-Elysées salonlarında 29 Aralık 1929 günü seslendirilir. Diğer bir programlı müzik örneği Rey'in ünlü piyanist Alfred Cortot'un 1930 'da Paris'te kurduğu orkestrası için yazdığı Enstantaneler'dir (Instantanés). Eser, Alfred Cortot yönetiminde 1932 yılında Paris'te École Normale de Musique Orkestrası tarafından seslendirilir. Rey, 1927'den 1940'lara kadar yapıtlarıyla Avrupa sanat merkezlerinin gündeminde kalır. 
1930-1931 Rey’in iki çeşit birikimini sergilediği dönemin başlangıcıdır. Bunlardan ilki, halk müziği ezgilerinin renklerini, çoksesli teknik içinde kullanarak halkın dilini konuştuğu eserler, diğeri senfonik ortamda betimleyici ve dramatik anlatım bulan eserlerdir. Bu eserlerin Batı'da kabul görmesinin en büyük nedeni, bestecinin yerel renkleri ustalıkla bu dokunun içinde kullanmasıdır. Rey, bundan sonraki on yıllık süreçte bir tercih yapmadan iki türde de eserler verir. 1931'den 1950'li yıllara kadar operetten senfoniye, konçertolardan marşlardan revülere, oda müziklerinden piyano parçalarına operaya kadar farklı formlarda yapıtlar üretir. Üstelik bu eserlerin kimlikleri birbirine karışmaz. 1942'de bestelemeye başladığı Çelebi operası en uzun süre çalışacağı eseri olur. 1950'li yıllara değin Türk makam müziği, İslam felsefesi ve Doğu renklerini Batı normlarıyla birleştirir. 1950 'den sonraki çalışmaları kendi düşsel sanatının ve olgunluk döneminin ürünleridir.

Bir bestecinin olgunluk döneminde üreteceği opera gibi çok yönlü sanat dalında Cemal Reşid'in genç yaşta eserler vermesi, Ekrem Reşid'in yönlendirmesiyle olur. İki kardeşin ürettiği “ortak eserlerinde bazen Ekrem Reşid'in önceden hazırladığı metinlere Cemal Bey müzik yazar, bazen de Cemal Bey'in önceden bestelemiş olduğu bir müzik çekirdeği Ekrem Bey' in sahneye uyarlamasıyla, yeni bir şekil bulur" (İlyasoğlu 2005: 50-51).

Cemal Reşid Rey için her zaman önemli olan: "Melodi, melodi ve yine melodidir. Melodi, romantik ve postromantik bestecilerin baş tacı olduğuna göre Cemal Reşid'i romantik olarak sınıflandırmak yanlış olmayacaktır." (İlyasoğlu 2005: 105). Diğer yandan "sanatının kökleri hem Batı hem de Doğu geleneklerine uzanan Rey'in eserleri daha geniş bir bakış açısından 20. yüzyıl Avrupasının çevre ülkelerinde gözlenen ulusalcılık akımının çizgisinde değerlendirilmelidir. Bestecinin uyguladığı halk müziğinin stilize tarzda işlenişi, 20. yüzyılın ulusalcı akımlarının yanısıra, Rus beşlerinin de uygulamış oldukları prensipler arasındadır" (Karlıbel 2008b: 76).

Türk Beşlilerin öncüsü Rey, ilk kez halk ezgilerini çokseslendiren, ilk büyük senfonileri, senfonik şiirleri, konçertoları, oda müziklerini, piyano parçalarını, sahne yapıtlarını yazan bestecimizdir. Rey, besteci Bülent Tarcan'ın deyimiyle: "Müzik tarihimizde Batı tekniği ile büyük ve enternasyonel çapta eser veren ilk simadır” (İlyasoğlu 2005: 126). 


\section{Ekrem Reşid Rey ve Cemal Reşid Rey Operaları}

\section{La Femme Fugitive (Kaçan Kadın)}

Opera Beş Perde

Selmi Andak, Cemal Reşid Rey'le yaptığı 13 Temmuz 1969 tarihli röportajında; "bu operanın 1917 yılında yazıldığını ve beş perdelik bir opera" (1969: 6) olduğunu belirtmektedir.

Hüsamettin Bozok "Ekrem Reşid Rey" başlıklı yazısında eseri; "La Femme Fugitive (1918, 5 perde opera)" (1950: 12) olarak tanımlamaktadır.

Libretto: Ekrem Reşid Rey tarafından Fransızca olarak yazılmıştır.

Yazılı̧ Tarihi: 1917 veya 1918

Cemal Reşid Rey'in La Femme Fugitive (Kaçan Kadın) isimli operasıyla ilgili ulaşabildiğimiz bilgiler son derece kısıtlıdır. Rey' in öğrencisi, besteci ve piyanist Dr. Aydın Karlıbel (2009: 20) şu bilgileri aktarmaktadır:

"Merhum Faruk Yener' in yapmış olduğu bir söyleşiden öğrendiğimize göre, Cemal Reşid Rey'in İsviçre'de bestelemiş olduğu ilk operası Kaçan Kadın ( $L a$ Femme Fugitive) başlıklı eserdir. Eser kayıptır ve tarihi bilinmemektedir".

Mahmut Ragıb Gazimihal (2006: 37), operayla ilgili şunları söylemektedir: "Ufak bir opera; fakat yarım kaldı: La Fugitive (Kaçan Kadın), keza kaybolmuştur. Livre kardeşi Ekrem Reşid Rey’e aittir”.

\section{Faire Sans Dire (Söylemeden Yapmak)}

Opera Bir Perde

Libretto: Ekrem Reşid Rey librettoyu, Alfred de Musset'in Faire Sans Dire (1836) adlı oyunundan yola çıkarak Fransızca yazmıştır.

Yazılış Tarihi: 1920

Illk Temsil: -

Rol Dă̆ılımı:

Mariani (Bariton)

Rahip (Abbe) Fiorasanta (Tenor)

Julia (Soprano)

Appiani (Bas) 
Orkestra: Eser piyano-şan partisyonu halindedir. Opera tamamlanmamıştır. Operanın konusu Dr. Aydın Karlıbel tarafından bu makale için tekrar düzenlenmiştir.

\section{Konu:}

Eserin tek perdesi şu bölümlerden oluşur:

No.1 Venedik doğumlu genç ve yoksul flütist Mariani evinde can sıkıntısı içinde yaşamaktadır. Flütünü hayranlık ve coşku ile eline alır ve bir arya söylemeye başlar.

No.2 O sırada rahip Fiorasanta ve sevgilisi Julia kapıyı çalıp, yardım isterler. İki sevgili büyük bir korku içindedir.

No.3 Mariani kapıyı açar, onları içeri alır. Fiorasanta ve Julia'yı yatıştırdıktan sonra, kendisini tanıtır. Rahip ve sevgilisi, Julia’nin kardeşi Appiani'den kaçmaktadır. Nitekim birazdan Appiani belirir. Mariani uzaklaşmaları için ikisine giyecek birşeyler vermek ister. Fiorasanta ise takviye bulup geri dönmek üzere evden ayrilır.

No.4 Julia gözyaşları içindedir. Kardeşinin kendisini öldürmesinden korkmaktadır ama ona bu fırsatı vermeden intiharı da düşünmektedir.

No.5 Genç kadın babasının matemini tutarken, eline aldığı hançerle intihar ve ölümden bahseder.

No.6 Mariani, Appiani'nin geldiğini farkeder. Bu arada Julia güzelliği ile Mariani'yi büyülemiştir.

No.7 Appiani eve girer, Mariani ile aralarında sert bir diyalog geçer.

No.8 Aryada Appiani kızkardeşine ailesinin onu mirasından reddettiğini, kimsenin onun adını anmadığını ve lanetlediğini söyler. Julie ithamlar karşısında Tanrı’ya yakarır.

No.9 Mariani ve Appiani arasında boğuşma başlar. Mariani, Appiani'yi öldürür.

No.10 Julia günahlarının affolunması için Tanrı’ya yakarır.

No.11 Cani kardeşini lanetler.

No.13 Mariani doğduğu şehir Venedik’i yadeden bir arya söyler. Bu sırada rahip Fiorasanta geri döner, Julia ise oradan uzaklaşmaya karar vermiştir. 


\section{No.14. Intermezzo}

Operada intermezzo No. XV ile "Bağlayınız" işareti ile sona erer fakat No. XV mevcut değildir, eser burada kesilmektedir (Karlıbel 2009: 20-21).

\section{Sultan Cem}

\section{Opera Oniki Tablo}

Prof. Dr. Yalçın Tura (2009a: 9-10) eserle ilgili görüşlerini şöyle dile getirir:

$\mathrm{Bu}$ operada on sekiz yaşındaki bir genç bestecinin gerek halk topluluklarının psikolojisini yansıtmada, gerek tek tek kişilerin ruhsal durumlarındaki değişimlerin alıını çizmede ulaştı̆̆ başarı düzeyi gerçekten dikkate değerdir. Bu başarıda Ekrem Reşid'in librettosunun payı da unutulmamalıdır. Halkın bekleyişinin canlandırıldığı birinci ve dördüncü tablolar, özellikle de onbirinci tablodaki Cem'in ölüm sahnesi, dramatik etki bakımından Mussorgsky'nin Boris Godunov'undaki benzer sahnelerden aşağı kalmamaktadır. Bu yapıın Cemal Reşid'in piyanoda seslendirdiği ilk üç tablosunu dinledikten sonra hocası Raoul Laparra’nın, eşine söylediği şu sözleri yapıtın değerini doğrulamaktadır: Eğer Cemal Fransız olsaydı bu yapıtıyla Roma Ödülünü mutlaka kazanırdı.

Libretto: Ekrem Reşid Rey tarafından Fransızca yazılmıştır.

Yazılı̧ Taribi: Ağustos 1922 - Nisan 1923

İlk Temsil: Eser henüz sahnelenmemiştir.

Rol Dağglımı:

\section{Erkekler}

Sultan Cem (Bariton ya da Tenor)

Bayezid (Bariton)

Papa VI. Aleksandre (Bas)

Sadrazam (Bas)

Pierre d'Abusson (Tenor)

Nadir (Tenor) 
Haberci (Tenor)

Müezzin (Sahnede Görünmez) (Tenor)

1. Mabeynci (Bariton)

2. Mabeynci (Tenor)

Hekim (Bariton)

Yaşlı bir kişi (Bas)

1. Nöbetçi (Tenor)

2. Nöbetçi (Bariton)

Yeniçeri Ağası (Bariton)

Yaşlı Adam (Tenor)

Bir Atlı (Tenor)

Bir Adam (Tenor)

4 Tatar Ulak (Tenor)

Soylular, Askerler, Yeniçeriler, Rodos Şövalyeleri, Harem Ağaları, Nöbetçiler, Uşaklar, Halktan Kişiler, Türbe Bekçisi (konuşmaz)

\section{Kadinlar}

Fidan (Soprano)

Helene (Mezzosoprano)

Valide Sultan (Kontralto)

5 Kadın (2 Soprano, 3 Kontralto)

Raks Eden Cariyeler

Halktan Kadınlar

Orkestra: Eser piyano şan partisyonu halindedir. Besteci eseri önce şan ve piyano için yazıp tamamladıktan sonra 2 flüt, küçük flüt, 2 obua, İngiliz kornosu, 3 klarnet, bas klarnet, 2 fagot, 4 korno, 2 trompet, kornet, 3 trombon, tuba, timpani ve öteki vurmalılar, celesta, 2 arp ve yaylılardan oluşan büyük bir orkestra için düzenlemeye başlamış fakat beşinci tablonun ortalarına doğru, orkestralamayı bırakmıştır. 


\section{Konu:}

\section{Tablo}

At koşturan Tatar ulakların hızla gelip geçişlerini betimleyen hareketli bir müzik üzerinde yeni Sultanın Bayezid mi yoksa Cem mi olacağını merakla bekleyen halkın konuşmaları ve tartışmaları işitilir. Kalabalık, yaklaşan şehzadeyi sevinçle karşılar.

\section{Tablo}

Valide Sultan ve cariye Fidan, sarayın penceresinden, deniz üzerindeki yoğun sis arasından, gelenin kim olduğunu seçmeye çalışmaktadırlar. Dışarıdan Yaşa Bayezid! seslerini işiten Valide Sultan üzüntü içindedir. Odaya giren harem ağası Nadir de gelenin Bayezid olduğunu fakat bir vezir ile Yeniçeri ağasının Cem'e sadık kaldıklarını ve onu beklediklerini söyler. Bunu duyan Valide Sultan, Cem'e durumu bildiren ve hemen gelip tahtı ele geçirmesini ögütleyen bir mektup yazdırır. Mektubu Cem’e ulaştırma görevini Fidan üstlenir.

\section{Tablo}

Cem yalnızdır. Ömer Hayyam'ın rübailerini okumakta, okumaya ara verip düşüncelere dalmaktadır. Bir mabeynci odaya girer ve İstanbul'dan dokuz Yeniçeri eşliğinde bir kadının geldiğini ve şehzadeyi görmek istediğini haber verir. Gelen Fidan'dır. Cem sevinçle ona sarılır. Fidan, Valide Sultan'ın mektubunu Cem'e verir ve tahtı ele geçirmesi için onu yüreklendirir. İlkin tereddüd eden Cem, Fidan'ın ısrarları karşısında kararını verir.

\section{Tablo}

Kocalarının Cuma namazından çıkmasını bekleyen halktan kadınlar aralarında konuşmakta ve durumlarından yakınmaktadırlar. Erkekler camiden çıktıkları sırada sahneye Cem ve askerleri girer. Cem, tahtı Bayezid'in elinden kurtarmaya kararlı olduğunu bildirir ve herkesi kendisine katılmaya çă̆ırır.

\section{Tablo}

Cem savaştan önce, çadırında düşünmektedir. Şafak sökmek üzeredir. Veziri gelir ve Cem'in ordusunda yabancıların, aslında ezeli düşmanları olan Rodos Şövalyelerinin yer almaması gerektiğini, kardeşi kardeşe kırdıracak 
olan bu savaşın haklı bir savaş olmadığını söyler ve çıkar. Yalnız kalan Cem, kendi kendine, bu savaşa Fidan için kalkıştı̆̆ını tekrarlar. Bir nöbetçi gelip Rodos Şövalyelerinin kumandanı ve Baş Rahip Kont d'Abusson'un görüşmek istediğini bildirir. Kont d'Abusson, körfezde on geminin demir atıp beklediğini ve başarısız olunursa Cem'in onlardan birine binip kaçabileceğini hatıllatır. Cem, öfkeyle, korkak olmadığını, savaşı kazanacağını haykırır ve askerlerine hücum emrini verir. Kıran kırana bir savaş başlar. Cem de savaşa katılır, fakat Bayezid'in ordusu daha güçlüdür. Cem’in askerleri arasındaki süvariler ve silahlı birlikler kaçmaya başlarlar. Kalanlar çarpışmayı sürdürmekte fakat birer birer vurulup düşmektedirler. Bu durum karşısında Cem bayılır. Kont d'Abusson ve yardımcıları telaşla onu alıp kaçırırlar.

\section{Tablo}

Rodos Şövalyeleri, aralarında konuşmakta, zorlu bir savaş olduğunu, Cem’in askerlerinin tümünün öldüğünü ve şehzadeyi güçlükle kurtarabildiklerini anlatmaktadırlar. Cem, ayılınca Fidan'ı sorar. Kont d'Abusson onu aradıklarını ama henüz bulamadıklarını ve bir an önce oradan kaçmaları gerektiğini bildirir. Cem ağlayarak onunla gider. Sahne bir an boş kalır. Gece bastırmıştır. Denizde uzaklaşan gemilerin ışıkları görünüp kaybolur. Uzaktan Cem'i arayan Fidan'ın sesi işitilir. Bayezid sahneye girer. Cem'in kaçırılışına üzülmüş ve kızmıştır. Bayezid'in askerleri Fidan'ı yakalayıp Bayezid'in huzuruna getirirler. Bayezid şaşırmıştır. Fidan'ın saraya gönderilmesini emreder. O sırada, Cem’i götüren gemiden atılan bir ok gelip Bayezid'in ayakları dibine saplanır. Okun ucunda bir kağıt takılıdır. Bayezid, kendisine uzatılan kağıdı açıp okumaya başlar. Kağıtta Cem’in şu sözleri yer almaktadır: "Behey zalim, senin zulmünden kurtulmak için düşmanlarımıza sığınmak zorunda kaldım. Ama Tanrı intikamımı alacaktır. Bir gün, senin çocukların da bana yaptıklarını sana yapacaklardır. Bayezid, bir an dalar, düşünür, sonra öfkeyle: Askerlerim kaçanları niçin yakalayamadılar? Buna sebep olanlar cezalandırılmalı. Hristiyan gemileri bir Müslüman şehzadeyi kaçırıyor ve bizler buna engel olamıyoruz. Utanılacak bir durum bu. Alnımıza leke sürüldü” diye haykırır. Yürür gider. Askerleri, başları öne eğik, yere basmaya korkarcasına, sessizce onun ardı sıra giderler. Perde ağır ağır kapanır. 


\section{Tablo}

Perde açıldığında Bayezid'in huzurunda rakkaseler raks etmekte, Fidan ise kaçıp Cem'in yanına nasıl gideceğini düşünmektedir. Bayezid, Fidan'ın gelip bir şarkı söylemesini buyurur. Fidan hüzünlü bir şarkı söyler. Bayezid, bu şarkıyı beğenmez ve ara verilmiş olan raksın yeniden başlamasını ister. $\mathrm{Bu}$ arada harem ağası Nadir sessizce yaklaşmış, Fidan da onun yanına sokulmuştur. Alçak sesle konuşurlar. Nadir, Fidan’a gece karanlığında sarayın duvarlarını aşabilmesi için bir merdiven bulunduğunu, bir Venedik gemisinin de sahilde onu bekleyeceğini haber verir.

\section{Tablo}

Karanlık bir sonbahar akşamı. Cem, Baron Jacques de Sassenage'ın kızı Helene'in gelmesini beklemektedir. Helene gelir. Babasının uyumasını beklemek zorunda olduğu için geç kaldığını, üstelik çok korktuğunu söyler. Cem ona korkmamasını, onu çok sevdiğini bildirir. İki sevgili uzaklaşırken ay çıkar ve ortalığı aydınlatır. Bir bekçi ile Fidan sahneye girerler. Bekçi Fidan’a Cem’in kaldığı kuleyi gösterir. O sırada Cem ile Helene konuşarak geri gelirler. Fidan, Cem’in yanında bir kadın olduğunu fark eder ve saklanarak iki sevgilinin konuşmalarını üzüntüyle dinler. Sonunda dayanamaz ve ağlayarak oradan uzaklaşır. Cem ile Helene de onun sesini işitmiş ve endişe içinde çabucak odalarına koşmuşlardır.

\section{Tablo}

Bayezid de sıkıntı içindedir. Fidan’ı düşünmektedir. Ona karşı karışı duygular beslediğini farketmiştir. Fidan Bayezid'in sarayına geri dönmüş fakat henüz onunla yüzleşmemiştir. Bayezid Fidan'ı yanına çağııır. Fidan gelir; sessizce ağlamaktadır. Bayezid ona dostça derdini sorar. Fidan, Cem’in artık kendisini sevmediğini, bir Hristiyan kadını sevdiğini açıklar ve ölmek istediğini söyler. Bayezid ise: "Asıl onlar ölecek, senin intikamını alacağım" der ve sevgiyle Fidan'a yaklaşır. Tam o sırada, uzaktan, bir müezzinin okuduğu ezan işitilir. Bayezid kendini toplar. Fidan ağlayarak odadan çıkar.

\section{Tablo}

Papa VI. Alexandre, Bayezid'in göndermiş olduğu bir ulakla pazarlık etmekte, Fransa Kralı VIII. Charles’’n Roma’yı kuşatmakta olduğunu, ona karşı sultanın yardımına güvenip güvenemeyeceğini sormaktadır. 
Bayezid, Cem’e karşılık Papa’ya üç yüz bin duka altını teklif etmiştir ve yardıma da hazırdır. Papa teklifi kabul ettiğini bildirir. O sırada Cem içeri girer. Ulağın kendi ülkesinden gelmiş olduğunu öğrenince ona çok özlediği vatanı hakkında sorular sorar. Cem konuşurken Papa da Cem'e sunacağı kadehe gizlice zehir koyar ve kadehi Cem'e uzatır. Uzaktan top sesleri gelir. Kuşatma başlamıştır. Cem dışarı çıkar. Papa kendi kendine söylenmekte, Kral Charles'in Bayezid'le dost olabilmek için Cem'i ele geçirmek istediğini, ama onun ancak cesedini ele geçirebileceğini söylemektedir. Perde, Papa’nın şeytanca kahkahaları arasında kapanır.

\section{Tablo}

Perde açldığında, bir hekim ve bir mabeynci uyumakta olan Cem'in yatağı başında konuşmakta ve günden güne ağırlaşan hastalığın nedenini anlayamadıklarını söylemektedirler. Cem uyanırken onlar da dışarı çıkarlar. Cem güçlükle yataktan kalkar, pencereyi açar ve bir koltuğa yığglır. Kendi kendine konuşur ve artık son gününün geldiğini söyler; yurdundan, dindaşlarından, sevenlerden uzakta öleceğinden yakınır. Papa onu Aziz Angelo şatosunda tutmak istemiş, Kral Charles ise Napoli’ye göndermiştir; her biri kendisinden yararlanmak istemiş, ama onun hiçbir işe yaramayacağını anlamamışlardır. Cem, atalarına, babası Fatih'e layık bir evlat olamamanın üzüntüsü içindedir. Tek yapabildiği iş kardeş kavgası başlatmak kardeşi kardeşe kırdırmak olmuştur. Bu düşünceler içinde iken, kulağına sesler gelir. Ölümüne neden olduğu binlerce askerin, o erlerin analarının, babalarının, dul karılarının, yetim çocuklarının yakınmalarını, ağlamalarını işitmekte, kendisi de pişmanlık içinde çırpınmaktadır. Babasının hayali karşısına dikilmiş, umutlarını boşa çıkaran bu değersiz oğul karşısında, gözyaşlarını göstermemek için yüzünü elleriyle örtmüştür. Cem birden ayağa kalkar: "Babacığım, neredesin" diye haykırır. Sonra Fidan'ı görür gibi olur, o da ağlamaktadır. Ona da seslenir: "Ölüyorum, diye ağlama Fidan’cığım. Kurtuluyorum.” Koltuğa yığılır. Gece bastırmıştır. Ay ışığı odayı aydınlatmaktadır. Cem sözlerine devam eder: "Ruhumun huzura kavuşması için dua et, Fidan. Buna ihtiyacım var. Beni bağışlaması için tanriya yalvar. Niçin titriyorsun? Şimdi ben de titriyorum. Ellerini ver bana. Ellerin buz gibi. Onların serinliği benim parmaklarıma da geçiyor. Soğuk, kollarımdan yukarı, bütün vücuduma yayılıyor. Kış bastırdı. Niçin her yer karanlık. Hiçbir şey göremiyorum. Fidan, neredesin, Fidan?” ve Cem son nefesini verir. 


\section{Tablo (Istenirse oynanmayabilir)}

Fidan, Cem’in mezarı başında, sesi titreyerek ve ağlayarak kendi kendine konuşur: "Cem sevgilim, işte bugün de senin yanındayım. Yüreğim kanıyor der. Sonra, olanları anımsar: O tatlı bir çocuktu. Sevmek, sevilmek ve güzellikleri anlatmak için dünyaya gelmişti. Ama Tanrı ona başka bir kader çizdi. Alnı, güllerden çelenkler için yaratılmıştı, buna karşılık o zafer çelenkleri takınmak istedi. Bu yüzden, kıskançlıkların, kinlerin hedefi oldu. Herkes ona kötülük yaptı. Ben bile ona kötülük yaptım. Ölümüne neden oldum. Bağışla beni sevgilim. Ruhlar âleminde sana kavuşabilmem için sen de bulunduğun yerde benim için dua et. Cem, Sevgilim benim.” Fidan hıçkırarak ağlarken perde yavaş yavaş kapanır (Tura 2009a: 4-9).

\section{L'Enchantement (Büyülenme)}

\section{Opera İki Perde}

Selmi Andak Cemal Reşid Rey'le 13 Temmuz 1969 tarihinde yaptığ 1 röportajda; bu operanın 1923 te Monte Carlo operası için Leon Jéhin’in isteğiyle bestelendiğini belirtmektedir (Andak 1969: 6).

Cemal Reşid, bu operasında, kendine özgü müzik dilini biraz daha geliştirmiş, orkestra yazısını biraz daha renklendirmiş olarak karşımıza çıkar. Yapıt, konusu bakımından, Debussy'nin Pelleas ile Melisande operasını çağrışıtırsa da, dramatik etkiye, kişileri tanıtıcı motivlere ve çizgisel dokuya önem veren müzik yazısı yönünden özgün ve ilgi çekicidir. (Tura 2009b: 4)

Libretto: Ekrem Reşid Rey tarafindan Madame Roussel Despierre'in senaryosu üzerine Fransızca yazılmıştır.

Yazılı̧̧ Taribi: 1924 Eylül-1925 Şubat

İlk Temsil: Eser henüz sahnelenmemiştir.

Rol Dăğllımı:

Tiphaine, 18 yaşında (Soprano)

Kont Guillaume, 50 yaşında (Bas ya da Basbariton)

Jean (Kontun Oğlu), 23 yaşında (Tenor)

Rollon (Kontun Kardeşi) 30 yaşında (Bariton)

Koro (Sahnede görünmez) (SATB) 
Orkestra: Eser piyano şan partisyonu halindedir. Yapıtta 3 büyük, bir küçük flüt, 2 obua, 1 İngiliz kornosu, 3 klarnet, 1 bas klarnet, 2 fagot, 4 korno, 3 trompet, 3 trombon, 1 tuba, timpani, üçgen, büyük davul, çan, 2 arp, çelesta ve yaylılar. Bestecinin orkestralamaya ne zaman başladığı belli değildir. 1 . perdenin orkestralamasını 166. sahifede tamamlayan besteci, 2. perdenin birinci sahnesinin ortalarında, 12. sahifenin sonunda, Rollon ile Kont'un konuşmaları sürerken orkestralamayı tamamlamadan bırakmıştır.

\section{Konu:}

\section{Perde}

Orta çağda, bir soylunun şatosunda, denize bakan büyük bir salon.

Kısa bir orkestra girişinin ardından perde açıldığında Rollon yalnızdır ve kendi kendine konuşmakta, gece olunca fırtına çıkacağını, denizdeki gemilerin tehlikede olduğunu söylemekte, kendi ruhunda da firtınalar estiğini, Tiphaine’in kendisini asla sevmeyeceğini düşünmektedir. Küçük yaşta anasız babasız kalmış, kontun şatosuna sığınmış ve orada büyümüş bir kız olan Tiphaine içeri girer, Rollon'u görünce korkup geri çekilmek ister. Rollon onu sevdiğini, kendisiyle evlenmek istediğini söyler. Kız ise onu sevmemekte ve karısı olmak istememektedir.

Kont içeri girer. Tiphaine, yalvararak, ondan kendisini korumasını diler. Rollon'dan korktuğunu söyler. Kont, onu avutmaya çalışır ve ona, karısı olmayı isteyip istemeyeceğini sorar. Tiphaine' in yanıtı olumludur. $\mathrm{O}$ sırada, limana büyük bir geminin girdiği görülür. Bayraklarından, bunun, kontun Asyàyı dolaşmaya gitmiş olan oğlunu getiren gemi olduğu anlaşılır. Kont oğlunu karşılamaya gider.

Tiphaine yalnız kalmıştır. Gemiden inen Jean'ı hayranlıkla seyreder. On yıl önce, o daha küçük bir kızken şatodan ayrılan Jean, şimdi yakışıklı bir delikanlı olarak geri dönmektedir. Tiphaine bir yandan sevinmekte, bir yandan da içinde bir korku duymaktadır.

Kont, oğluyla birlikte salona girer. Jean ile Tiphaine, birbirlerini görür görmez, büyülenmiş gibidirler. Gözlerini birbirlerinden ayıramazlar. Kilisenin çanları çalmaya başlar. Kont dua için kiliseye gider.

Jean'la Tiphaine baş başa kalırlar ve görür görmez birbirlerine aşık olurlar. Ve bu aşkı açığa vurmaktan kaçınmazlar. Tutkuyla öpüşürler. Kont döndüğünde onları daldıkları düş içinde bulur. 
Kont şölen hazırlığı için Tiphaine’le birlikte salondan ayrılır. Yalnız kalan Jean, sevmenin ve sevilmenin mutluluğu içindedir. Rollon gelir ve ona bu durumun nedenini sorar. Jean'ın Tiphaine’i sevdiğini ve sevgisinin karşılıksız kalmadığını öğrenince, dehşetle, aklını başına toplamasını, o kızdan uzak durmasını, çünkü Tiphaine’i seven kişiyi ölümün beklediğini haykırır. Jean, ona, ölümden, hele Tiphaine’ in kollarında ölmekten hiç korkmadığını söyler.

Gecenin karanlığı, birden, meşalelerin alevleriyle aydınlanır. Korodan bir sevinç ve mutluluk ezgisi yükselir. Kont ile Tiphaine salona gelirler. Tiphaine'in gözleri yaşlarla doludur. Kont, Jean ile Rollon'a, Tiphaine’le evleneceğini açıklar ve Rollon'la birlikte sahile doğru uzaklaşırken, Jean’a da, arkalarından işaret eder. Tiphaine, salonda yalnız kalmıştır. Perde ağır ağır kapanır.

\section{Perde (Kesintisiz birbirine bağlanan beş sahneden oluşmaktadır.)}

Şatonun bahçesinde, denize bakan bir teras. Sık ağaçlar. Geçen bulutlar, ara sıra, ay ışı̆̆ını karartmaktadır.

Yaylı sazlarda taklitlerle başlayan çok kısa bir girişin ardından perde açıldığında kont, Rollon'a kendisine ne söylemek istediğini sormaktadır. Rollon, söyleyeceklerinin onu üzebileceğini belirtir. Sonunda dili çözülür, konta genç olmadığını hatırlatır ve Tiphaine’le evlenmesinin sakıncalarını anlatmaya çalışır. O genç kızın sevmeye ve sevilmeye ihtiyacı vardır; kontu ancak bir baba gibi sevebilir çünkü bir başkasını sevmektedir. Kont: Yalan diye haykıırr; Rollon'dan, bu iftirasını kanıtlamasını ister. Rollon, biraz sabırlı olursa, ona bunu ispatlayacağını söyler. Kont, Tiphaine’i elinden almaya çalışanı, kim olursa olsun, çekinmeden öldüreceğini bildirir. Rollon, ona, odasına dönmesini, zamanı gelince, kendisine haber vereceğini söyler. Kont ayrılır. Rollon da gitmek üzere iken, ayak sesleri duyar ve saklanıp gözetlemeye koyulur.

Gelen Tiphaine'dir. Jean'ı beklemektedir. Kontun karısı olacağı için çok üzgündür. Derdini yıldızlara anlatmakta ve ağlamaktadır. Rollon saklandığı yerden çıkar ve ona niçin ağladığını sorar. Yakınmalarını işitmiştir. $\mathrm{O}$ da en az onun kadar üzüntülüdür. Kıza, Jean'ın tehlikede olduğu yalanını söyler. Kont herşeyi öğrenmiş ve Jean'ı oradan uzaklaştırmaya karar vermiştir. Tiphaine için en iyi çözüm, hemen o gece, Jean'la birlikte şatodan kaçıp gitmek olacaktır. 
Rollon gider. Tiphaine, ne yapacağını bilemeden ağlamaktadır. Jean gelir. İki sevgili birbirlerine sarılırlar. Tiphaine ona Rollon'dan işittiklerini anlatır. Jean, üzülmemesini, kendilerini kimsenin ayıramayacağını söyler.

İki sevgili, birbirlerine aşk yeminleri ederken, Rollon, kontla birlikte geri döner. Kont, Tiphaine’in yanındaki gencin, kendi oğlu Jean olduğunu fark eder. Gerçeği anlamıştır. Elindeki hançeri yere firlatır. Durumuna ne kadar üzülse de, fedakârlık ona düşmektedir. Kendisi yaşamının sonuna yaklaşmıştır. Mutluluk gençlerin hakkıdır. Doğru olan Tiphaine ile Jean'ın evlenmesidir.

Fakat Rollon, işittikleri karşısında kıskançlıktan kıvranmaktadır. Kontun elinden bıraktığı hançeri yerden alır ve Jean'ın sırtına saplar. Jean yere düşer. Rollon kaçar. Kont onu yakalamak için arkasından koşar.

Tiphaine, Jean'ın üstüne kapanır, onu kucaklar. Ölmemesini, mutlu olacaklarını söyler. Jean, Tiphaine'i öper. Son bir gayretle doğrulur fakat kızın ayakları dibinde yere yığılır. Tiphaine de, Jean’ın öldürüldüğü hançeri kaparak kendi yüreğine saplar. $\mathrm{O}$ da Jean'ın ölüsünün üzerine yığılır ve can verir. Perde hızla kapanır (Tura 2009b: 3-7).

\section{Zeibek (Zeybek)}

Opera $\ddot{U}_{c}$ Perde

Libretto: Ekrem Reşid Rey tarafından Fransızca yazılmıştır.

Yazılış Tarihi: 2 Nisan 1928

İlk Temsil: Eser henüz sahnelenmemiştir.

Rol Dă̆ılımı:

Saadet (Dramatik Soprano)

Veli (Tenor)

Recep (Bariton)

Baba (Bas)

Bir Çoban (Tenor)

Hemşire (Kontralto) 
8 Kadın (4 Soprano, 4 Mezzosoprano)

Zaptiyelerin Başı (Bariton)

İki Arabacı (Tenor ve Bariton)

Zeybekler Kafilesi - Koro

Orkestra: 3 flüt, piccolo, 2 obua, korangle, 2 klarnet (si bemol), 1 bas klarnet, 2 fagot, kontrfagot, 4 korno ( $\mathrm{Fa}), 3$ trompet, tuba, timpani, ksilofon, çıngıraklar (Fransızca "Grelots" olarak belirtilmiş), 2 dümbelek, 2 arp, grancassa, tamtam, zil, üçgen, çello, yaylılar.

Eser piyano şan partisyonu halindedir. Piyano-şanın 110. ve 111. sayfaları eksiktir. 1. perde 74, 2. perde 62, 3. perde ise 101 sayfa uzunluğundadır. 1. ve 2. perdeler arasinda bir intermezzo vardır. Esere ait orkestra partisyonu sadece 24 sayfadır ve tamamlanmamıştır. 24. sayfa 1. perde, 2. sahnenin başına isabet etmektedir. Libretto 37 sayfa uzunluğundadır.

Zeibek (Zeybek) operasının okunması güç halde olan piyano şan partisyonu besteci ve piyanist Dr. Aydın Karlıbel tarafından temize çekilmiştir.

Operanın konusu Dr. Aydın Karlıbel tarafından bu makale için tekrar düzenlenmiştir.

Kопи:

Olay 19. yüzyılda geçer.

\section{Perde}

Dağda yüksek kayalıkların ortasında bir alanda küçük bir İzmir halısı üzerinde, Veli, Baba lakaplı zeybek, Recep ve diğer zeybekler uzanmışlardır. Keyifle nargilelerini tüttürmektedirler. Recep şiddetli bir çatışmayı anımsar. Adamları asker kurşunlarına hedef olmuş, kendisi de ölümden dönmüştür. Onları Veli kurtarmıştır. Veli, bir zeybek için yardım etmenin kutsal olduğunu anlatır. Ardından Sakallı Baba'ya seslenerek kendilerine yemek hazırlamasını ister. Kuzu eti, pilav, karpuz, üzüm ve helva hazırlanır, ateş yakılır. Ateşin etrafında oniki zeybek kimi oturmuş kimi yere uzanmış koro halinde yüksek sesle, kahkaha ve nidalarla eğlenirler. $\mathrm{O}$ sırada yaklaşan kervanı fark edince silahlarıyla dışarı firlarlar. Çıngırak sesleri arasında kervan gelir. Zeybekler kervandaki yolcuları esir alır. Yolcular kendilerine kötülük yapılmaması için yalvarırlar. Veli esirlerin arasından Saadet’i farkeder. Ona yaklaşır ve 
onunla ilgilenir. Saadet, babasının zengin olduğunu, serbest kalması için kendilerine fidye verebileceğini söyler. Veli onun diğer kadınlardan farklı olduğunu ve korkmadığını anlar. Peçesini açıp yüzünü görmek ister, ona üzüm ikram eder.

\section{Perde}

Sıcak bir öğleden sonradır. Çardağın altında yarı uzanmış genç bir çoban kaval çalmakta bir ezgi mırıldanmaktadır. Çok geçmeden iki sevgili Veli ve Saadet görünür. Aşklarını anlatan uzun bir düet yaparlar. Çeşmenin etrafında selelere yaslanmış zeybekler görünür. Veli rakı içerken, Recep ve Baba’yı da birlikte içmeye davet eder. Perde, Recep’in başını çektiği, zeybeklerin de katıldığı coşkulu toplu bir zeybek dansı ile sona erer.

\section{Perde}

Saadet' in oturduğu evin bahçesi görünür. Saadet divanın üzerinde, sütannesi de onun karşısında, çınarların gölgesindedirler. Sütanne yün eğirmekte ve ipliğin ucundaki bezi çevirmektedir. Birbirleriyle dertleşirken çok geçmeden Veli gelir. Saadet sevgilisinden ayrı kaldığında çektiği acıyı dile getirir. İki sevgili birbirlerine duydukları aşkı anlatır. Veli sevdiğini atıyla dağa kaçırmayı teklif eder. Saadet kabul eder.

Zaptiyeler ve Saadet' in babası gelir. Baba, kalabalığa kızını Veli'nin elinden kurtarmaları için yalvarmaktadır. Kalabalığın arasında Saadet ve Veli görünür, tartışmaktadırlar. Veli, Saadet'i yalancılıkla, parayı aşkına tercih etmiş olmakla suçlar. Saadet inkâr eder. Veli, Saadet'i kendisini aldattı̆̆ını söyleyerek bıçaklar. Saadet yere düşer. Veli pişmanlık içinde kendisini öldürmek ister. Kalabalık ona engel olur. Veli’yi bağlayıp götürürler. Baba, hemşire ve birkaç komşu genç kızın üzerine eğilmişlerdir. Perde yürek dağlarcasına Saadet'in ölümü ile biter (Karlıbel 2009: 22-23).

\section{Drame Anatolien (Köyde Bir Facia)}

\section{Opera Bir Perde}

Prof. Dr. Yalçın Tura (2009c: 3-4) eserle ilgili görüşlerini şöyle dile getirir:

Bestecinin, bu yapıtında, Türk halk müziğini iyice özümsediği ve bilinen belli ezgileri doğrudan kullanmak yerine onların üslübuna aykırı düşmeyen ama kişisel ezgiler yaratma yolunu yeğlediği görülmektedir. Bu bakımdan, bu yapıt, Türk operasının oluşum 
süreci içinde önemli bir köşe taşı sayılabilecekken, orkestralanmadan ve sözleri Türkçeye aktarılmadan bir köşeye atılıp kaldığı için bugüne değin, ne yazık ki böyle bir işlevi yerine getirememiş, bestecinin ortaya çıkmamış pek çok yapıtı gibi, bu çok değerli yapıt da, boşa harcanmış, ziyan olmuş bir emek ürünü olarak unutulup gitme talihsizliğine uğramıştır.

Prof. Dr. Yalçın Tura operayı Türkçeye çevirerek ve orkestrasyonunu yaparak temsil edilebilir hale getirmiştir.

Libretto: Ekrem Reşid Rey tarafından Fransızca yazılmıştır.

Yazılış Tarihi: 30 Temmuz 1929-13 Eylül 1929

İlk Temsil: Eser henüz sahnelenmemiştir.

Rol Dă̆ılımı:

Bebek (Sessiz Rol) Eserde görünmemektedir

Ana (Mezzosoprano)

Ali (Tenor)

Emine (Soprano)

Orkestra: Eserin orkestra düzenlemesi yapılmamıştır. Eser, piyano şan partisyonu halindedir.

\section{Konu:}

Yapıt, Cemal Reşit'in, bundan önce yazdığı, üç operanın aksine, yaklaşan dramı önceden hissettiren balta vuruşlarını da yansıtan uzunca bir orkestra prelüdü ile başlar.

\section{Sabne}

Ana dışarıda, kapının önünde, kocaman bir balta ile odun kırmaktadır. Emine gelir. Üç aydan beri haber alamadığı askerdeki kocasından mektup gelip gelmediğini öğrenmek için köy imamına gitmiştir. Kocası Ali’den bir haber yoktur. İmamın yanında Ali gibi askere gitmiş olan Rıza’nın karısı Fatma’yı görmüş, imamın Fatma’ya, kocasının ölüm haberini ve ondan kalan tütün tabakası ile saati verişine şahit olmuştur. Üzüntü içindedir. Geceleri kötü düşler görmekte, kocası Ali'nin sağ olarak geri dönüp dönemeyeceği 
kaygısıyla kıvranmaktadır. Ana, içeri girip, elindeki baltayı bırakır ve gelinini avutmaya çalışı; ona, düşleri iyiye yormasını öğütlerler. Konuyu değiştirmek için, o gün işittiği bir olayı anlatır. Komşu kadınlardan biri, oduncu Ahmed'in karısı Halime, bir adamla, çoban Mevlüd'le basılmış ve köyde kimsenin yüzüne bakamayacak duruma düşmüş, aşığı da iyi bir dayak yemiştir. Ahmed askerden dönüp de durumu öğrenirse mutlaka elini kana boyayacak ve bu yüzden hapse düşecektir. Yaşlı kadın, bu gibi ahlaksız kimseleri yaşatmamak, öldürmek gerektiğini, namus lekesinin ancak kanla temizlenebileceğini söyler. Sonra, havayı değiştirmek ve Emine’yi oyalamak için, koyunlardan, kuzulardan kümeslerindeki tavuklardan söz eder. Sonra da, uyumak için odasına çekilir.

\section{Ninni}

Gece bastırmıştır. Emine, bebeğini uyutmak için ona ninni söylemeye başlar. Sevgili kocası, bebeğinin babası çok yakında gelecek, ailenin üzüntüleri sona erecektir.

\section{Sahne}

Emine uyumaya çalışırken kulübenin kapısı sessizce aralanır. Gerçekten, kocası Ali gelmiştir. Emine sevinçle ona sarılır. Ali de bir an önce evine kavuşmak için sabahı beklememiş koşarak gelmiştir. Emine, anayı da uyandırmalarını söyler ama Ali, yaşlıdır diyerek ona engel olur. Karı koca birbirlerine sarılıp uykuya dalarlar.

\section{Interlude}

İç perde kapanır. Sahne kararır. Orkestradan iki dakika kadar süren bir ara müziği işitilir.

\section{Son Sahne}

Sabaha doğru uyanan Ana, Emine’nin koynunda bir erkeğin yattığını görünce, Halime’nin olayının kendi başına de geldiğini sanarak deliye döner. Baltasını kaptığı gibi, yatakta uyuyan adamın başına indirir. Fakat onun Ali olduğunu anlayınca dehşetle haykırır. Yaşlı kadın, öz oğlunu kendi eliyle öldürmüştür (Tura 2009c: 4-6). 


\section{Çelebi}

\section{Opera Dört Perde}

Libretto: Ekrem Reşid Rey tarafından Türkçe ve Fransızca olarak yazılmıştır.

Yazılı̧ Tarihi: Eserin ilk versiyonu besteci tarafından 1942 ile 1945, son versiyonunun orkestra partisyonu 1973 'te, piyano-şan partisyonu 1975 'te tamamlanmıştır.

İlk Temsil: Cemal Reşid Rey'in 4 perdelik Çelebi operasının ilk seslendirilişi Konser Uygulaması olarak Aydın Gün Anısına 7 Mayıs 2010'da Kadıköy Belediyesi Süreyya Operasında yapılmıştır (İDOB 2011:2).

Rol Dă̆glımı:

Çelebi (Tenor)

Fatma (Lirik Soprano)

Tahsin Efendi (Komik Tenor)

Hasan Çavuş (Bariton)

Sadrazam (Bas-Bariton)

Rebeka (Dramatik Soprano)

Perla (Alto)

Safiye (Soprano)

Atiye (Mezzosoprano)

Zübeyde (Alto)

Konuşma Rolleri (Baba (Haydar), Anne, İmam, Şair Nedim, Şair Sami)

Koro (Saraylılar, Yeniçeriler, Halk)

Orkestra: 2 flüt ve piccolo, 2 obua ve korangle, 2 klarnet (si bemol), 2 fagot, 2 korno $(\mathrm{Fa}), 2$ trompet (Do), 3 trombon, tuba, timpani. Vurmal sazlar: gran cassa, tam-tam, ziller, üçgen, kamçı, def, mehter takımına dâhil nakkareler ve çevgân. Arp, çelesta, yaylılar (Karlıbel 2008a: 11).

Копи:

Olay Lale devrinde III. Ahmet döneminde geçer. 


\section{Perde}

Edirne'de, Yeniçeri Birliği mehterhaneyle resmigeçit halindedir. Genç mehterbaşı Hasan Çavuş evinin penceresinden dışarıya bakmakta olan yaşlı bir yeniçeri olan Fatma’nın babasına, Fatma'ya gönül verdiğini ve onunla evlenmek istediğini söyler. Fatma’nın babası da ona: Kızımı sana veririm ama önce savaşa git, zaferle dön! der. Hasan Çavuş neşeyle uzaklaşır. Anne gelir ve kızının Hasan Çavuş'la evlenmesinde ısrar eder.

Kızları Fatma gelir. Annesi başına gelecekleri kızına anlatır. Fatma buna çok üzülür, anne de üzgün ve çaresizdir. $\mathrm{O}$ anda bir delikanlı görünür, bu Çelebi'dir. Genç adam olan biteni anlayınca kederini açıklamaktan kendini alamaz.

Fatma’yla Çelebi kaçmaya karar verirler, ama kızcağız buna cesaret edemediğinden kararsızdır. Çelebi, sevgilisinin bu kararsızlığına üzülür ve onu vefasızlıkla suçlayarak çıkar gider. Fatma da: Çelebi, Çelebi! diye haykırarak yere yığılır.

\section{Perde}

Anadolu Hisarı görülür ve uzaktan Çelebi'nin sesi duyulur. Çelebi kayıkla gazel okuyarak gelir. Yanında Şair Nedim ile Şair Sami gibi zamanın iki ünlü şairi de vardır. Çelebi Fatma’ya olan tükenmez aşkını açıklar, iki büyük şair de ona şiirlerini okurlar (parlanda). Çelebi yalnız kalır ve üzüntüyle Fatma'yı sayıklar.

Sahne değişir ve Çelebi'yi elde etmeye çalışan üç kadının (Atiye, Zübeyde, Safiye) düzenledikleri şen şakrak bir içki âlemi görülür. Çelebi, yeni yazmış olduğu bir eseri okumaya koyulur. O sırada kadınlar düşüncelerini üç ses olarak adeta mırıldanarak dile getirirlerken orkestra da bu coşkulu aşk sahnesini destekleyerek güçlendirir ve perde bir mest oluş havası içinde sona erer. Söz konusu beste, Hüseyin Sadettin Arel tarafından Cemal Reşit Rey’e verilmiş olan Müezzin Çelebi'nin özgün bestesi Şehnaz Buselik Semaidir. Üç kuple olarak tekrarlanılan bu parçayı Çelebi önce def eşliğinde a cappella söyler. Daha sonra tekrarlanan iki kupleye orkestra da katılır.

\section{Perde}

İstanbul'da sadrazamın gözdesi Rebeka’nın evinin içi görülür. Rebeka büyük bir özlemle çok sevdiği Çelebi’yi beklemektedir. Annesi Perla gelir ve kızının 
Çelebi'ye duyduğu ilgiyi sezerek kuşkulanır çünkü kızının sadrazamla ilişkisine engel olacak herşeye karşıdır.

Sadrazam kendi adamı Tahsin Efendi'yi Rebeka'yı izlemekle görevlendirmiştir. Tahsin Efendi'nin gelişi, Rebeka’nın canını sıkar ama sadrazamın gelmek üzere olduğunu da ondan öğrenir. Rebeka sadrazamın Çelebi'yle karşılaşmasından korkar ve onun gelmesini önlemek için annesini Çelebi'ye gönderir. Anne Çelebi' yi bulamadan döner. Kapı açılır ve sadrazam içeri girerken anne sıvışıverir.

Sadrazam, Rebeka'nın boynuna bir inci gerdanlık takar ama Rebeka'nın sevinci korkusunu gideremez. Rebeka sadrazamı oyalamak için heyecanla dans etmeye başlar ve sonunda sadrazamın dizlerine kapanır; bir bahane bularak Tahsin Efendi'den yakınır. Tahsin Efendi de Çelebi'yle gözdeler arasında olup bitenlerden sadrazamın sezinleyebileceği bir şekilde söz eder.

Sadrazam, Çelebi'yi sürdürmeye karar verir. O sırada Tahsin Efendi gelir ve sadrazama padişah hazretlerinin kendisini çağırdığı haberini verir. Sadrazam gider. Rebeka’nın hali haraptır. Kapı açılır ve Çelebi girer. Rebeka ona gözdelerle geçirdiği içki âleminden yakınır. Çelebi onu yatıştırır.

O sırada mahalleli baskın yapar ve başlarında imam olduğu halde kapıyı kırıp içeri girerler. Çelebi kılıını çektiği gibi karşılarına dikilir. $\mathrm{O}$ anda sadrazam gelir. Çelebi saklanır, imam da onu Rebeka’nın sevgilisi olarak ortaya çıkarıp ele verir. Sadrazam, ikisinin de kellerinin uçurulmasını emreder, Rebeka bayılır. Çelebi de pencereden atlayıp gider.

\section{Perde}

Olay birkaç yıl sonra Edirne'de geçer. İhtiyar yeniçerinin kızı Fatma evinin önünde görülür ve acısını dile getirerek eve girer. Sahnenin gerisinden, bitkin ve pejmürde halde Çelebi gelir; halinden yakınır, Fatma'nın kapısını vurur. Kapı açılır ve Fatma görünür; irkilir neye uğradığını anlayamaz. Çelebi, Fatma'ya: "Hadi gidelim!" der. Fatma, olamayacağını söyler çünkü anası babası ölmüş, kendisi de Hasan Çavuş’la evlenmiş, iki çocuğu olmuştur. Fatma: "Artık herşey bitti, benim artık burada kalmam gerekiyor" der.

Çelebi bitkin bir halde oradan uzaklaşırken, Fatma: "Dur!" diye haykırır ve elinde bir çıkınla evden dışarı çıkar; Çelebi'ye yaklaşarak çıkını verip yine eve girer. Çıkının içindekiler, yıllarca önce Çelebi'nin kendisine vermiş olduğu 
şeylerdir. Çelebi gider. Hasan Çavuş camidedir, ama camiye gitmeden önce karısına etrafta haydutlar dolaşı̆̆ı için kapıyı kimseye açmamasını tembih etmiştir. O sırada Çelebi, bahçe kapısının açık kalmış olmasından kuşkulanır. Bir türlü uzaklaşamamıştır. Dönüp tekrar gelir: "Fatma!" diye bağırarak kapıya vururken bir patlama olur; birinci katın penceresinden uzanan bir piştov, Çelebi'yi eve baskına gelen bir haydut sanarak vurup yere sermiştir. Hasan elinde fener ve piştovla dışarı çıkar; Fatmảyı çağırarak, elindeki fenerle yerde yatanın yüzünü aydınlatır: "Gel bak! Bu tanıdık mı?" diye sorar. Fatma: "Tanımıyorum" der. Hasan, karakola haber vermek için oradan uzaklaşır. Fatma ağlayarak Çelebi'ye koşar.

$\mathrm{Bu}$ arada melekleri dile getiren kadınlar korosu perdenin sonuna kadar kah hafifleyip kah kuvvetlenerek Arpaeminizade Mustafa Sami'nin mersiyesinden alınmış olan sözleri terennüm ederler.

Ağır yaralı olan Çelebi başını kaldırır: "Sen mutlu ol, Fatma!" der ve son nefesini verir. Fatma da Çelebi'nin üstüne kapanırken perde iner (Karlıbel 2015: 41-42).

\section{Sonuç}

Ekrem Reşid Rey ve Cemal Reşid Rey ülkemizde çoksesli müziğin yaratılması ve tanıtılması bakımından öncü kişiliklerdendir. Sahne için yazdıkları operet ve revülerin çoğu sahnelenirken, operalarından biri bile bütünüyle sahnelenmemiştir. Çelebi dışında tüm operaları piyano şan için yazılmış, orkestrasyonu tamamlanamamıştır. Rey operalarıyla ilgili: "Zeybek'ten sonrakiler kendi şahsiyetini bulmuş bir bestecinin verimidir" tanımlamasını yapar. La Femme Fugitive (Kaçan Kadın) (1917 veya 1918) kayıp, Faire Sans Dire (Söylemeden Yapmak) (1920) tamamlanmamış operalardır. Cemal Reşid, 1922 Ağustos’unda Cem Sultan'ı yazmaya başlar. Piyano şan eşliğini 1923 yılı Nisan ayında tamamlar. Solistlerin yanı sıra bu eserde koroya önemli bir yer verir, büyük bir orkestra kullanır. Beşinci tablonun sonunda eseri orkestralamayı bırakır. 1924 yılının Eylül ayında Madame Roussel Despierre'in senaryosu üzerine Ekrem Reşid'in librettosunu yazdığı L'Enchantement (Büyülenme) adlı iki perdelik yapıtının piyano şan eşliğini 1925 'in Şubat ayında tamamlar. Sahnede görünmeyen karma bir koroya yer verdiği bu eserde, kalabalık bir orkestra kullanarak, ikinci perdenin ilk sahnesine doğru orkestrasyonu bırakır. 1928 yılında yazmaya başladığ 
üç perdelik Zeibek (Zeybek) operasını 2 Nisan 1928'de piyano şan eşliğini tamamlar. Bu eserde şan partilerinin yanı sıra koroya da önem verirken, daha önceki operalarında olduğu gibi uvertür yer almaz. 1.Perde ile 2.Perde arasında bir intermezzo bulunmaktadır. Yine büyük bir orkestra kullanarak orkestrasyona başlayan besteci birinci tablonun sonunda orkestralamayı bırakmıştır.

Rey, 30 Temmuz 1929'da Drame Anatolien (Köyde Bir Facia) adlı eseri şan piyano için bestelemeye koyulur. 12 Eylül 1929 'da tamamlar. Diğer operalarında farklı olarak, yaklaşık beş dakika süren bir prelüdle operaya başlar. Birinci sahnenin sonuna doğru bir ninni, birinci sahne ile son sahne arasında bir interlüd bulunmaktadır. Cemal Reşid Rey’in öğrencisi Prof. Dr. Yalçın Tura, Rey’in eserinde Türk halk müziğinin üslübuna aykırı düşmeden kişisel ezgiler yaratma yolunu seçtiğini ve Drame Anatolieñin (Köyde Bir Facia), Türk operasının oluşum süreci içinde önemli bir köşe taşı kabul edilebileceğini vurgular. Tura, orkestrasyonu yapılmamış ve Türkçeye aktarılmamış bu eseri; baştan sona orkestra için düzenlemiş, Türkçeye çevirerek temsil edilebilecek duruma getirmiştir.

Cemal Reşid Rey’in yazdığı operalardan sadece Çelebi operası hem Fransızca hem Türkçe yazılmıştır. Çelebi dışındaki bütün operalar Fransızcadır. Eser, Rey'in orkestrasyonunu yapmış olduğu tek operadır. Bu eserlerin yazıldığı dönemde Türkçe opera oynanması bir hayaldir. Sanatçıların operaları Fransızca yazmasının nedeni; Fransızcanın birkaç yüzyıl önce opera dili olarak benimsenmiş olması ve evrensel boyuttaki bu eserlerin uluslararası düzeyde icra edilmesini, anlaşılmasını sağlamaktır. Rey, daha sonra yazdığı sözlü yapıtlarında genellikle Türkçe metnin altına Fransızca çevirilerini de koymuştur.

Dr. Aydın Karlıbel, Çelebi operasıyla ilgili makalesinde (2008b:7576) eserle ilgili şu bilgileri vermektedir: Rey "Çelebi”nin tarihimize ait bir konuyu içermesi, hem dünyevi hem mistik temaları ele almış olması nedeniyle üzerinde ayrı bir özenle çalışıştır. Operadaki sahneler, karakterler ve dramatik atmosfer çeşitliliğe sahiptir. Eserin dört perdesi farklı karakterde olup, I. lirik, II. komik, III. dramatik ve IV. trajik olarak tanımlanabilir.

Opera geleneklerine uygun olarak, Çelebide ileriye doğru akış, 
karakterlerin giderek perde sonlarına doğru oyuna katılmaları sağlanmaktadır. İki önemli kadın karakterden Fatma’nın kocası ve aşkı arasındaki mücadelesi, İtalyan şair ve libretto yazarı Pietro Metastasio'nun (1698-1782) librettolarının unsurlarından olup, birçok önemli Fransız operasında bulunmaktadır. Çelebiden müzik ve aksiyon, müzikal ve teatral ifade birbiriyle büyük bir uyum arzeder.

Bestecinin uyguladığı halk müziğinin stilize tarzda işlenişi, 20. yüzyılın ulusalcı akımlarının yanısıra, Rus beşlerinin de uygulamış oldukları prensipler arasındadır. Yine opera tarihinde folklorun ilk defa geniş ölçüde yer aldığı Bizet'nin Carmen operası da hem bu açıdan, hem de Metastasio tarzında bir aşk üçgenini içermesi açısından Çelebi ile benzerlikler arzeder.

Mallarmé ve Baudelaire'in kıtaları kadar Ömer Hayyam'ın rubailerini de ezbere bilen Cemal Reşid Rey'in operasında tasavvufi düşüncenin, eserin daha derinde yatan ifade düzeyini oluşturduğu söylemek mümkündür. Aşk, güneş, ayrılık ve kavuşma (vuslat) gibi temalar Rey'in engin iç dünyasının beslendiği mistisizm ile aslında büyük bir aşk alegorisi olan Çelebi operasında müziğin ötesindeki anlamlarla yüklü olan boyutunu sergilemektedir.

Özgün bir başyapıt olan Çelebi, gerek boyutları nedeniyle gerekse teknik düzey açısından icrası güç fakat Rey kardeşlerin renkli, fantezi dolu yaratılarının ve iki sanatçı kardeşin işbirliginden doğmuş olarak müzik tarihinde eşine ender rastlanan bir eserdir.

Besteci şan ve piyano düzenlemesini 1945 'de tamamladığ Çelebi operasını, uzun bir aradan sonra yeniden ele alarak orkestralamaya başlamış, ömrünün son yıllarına dek bu yapitın orkestralanması ve seslendirme materyalinin hazırlanmasıyla uğraşmıştır. Çelebiden seçme aryalar; 1974, 1976 ve 1977 yıllarında, Mustafa İktu ve Suna Korad'ın yer aldıkları konserlerde Venüs Tiyatrosu, Zeynep Kamil Hastanesi Sahnesi ve 5. İstanbul Festivali açılış konserinde icra edilmiştir.

Cemal Reşid'in “en büyük eserim” dediği Çelebi’nin hikayesi Ekrem Reşid'in 1943 yılında radyo için bir skeç yazmasıyla başlar. Skeç büyük ilgi görünce bu konudan hareket ederek bir opera librettosu hazırlar. Çelebi'yi manzum olarak hem Türkçe hem de Fransızca yazar. Eseri bestelemeye başlayan 
Cemal Reşid, Müezzin Çelebi'den günümüze kadar gelen özgün bir şarkıyı da ekleyerek eseri üç yıl içinde tamamlar. Besteci 1969-1973 arasında operayı yeniden ele alır.

Çelebi 1978-1980 yıllarında Gürer Aykal'ın müdürlüğü sırasında Ankara Devlet Opera ve Balesi tarafından satın alınarak kurumun zimmetine geçirilir. Rey, 1984 yılında, dördüncü perdeyi bitirince eseri İstanbul Devlet Opera ve Balesi müdürü Orhan Tanrıkulu'na teslim eder. Bu perde, İstanbul'dan Ankara’ya gönderilir. Ancak eser Ankara'ya ulaşmaz. Tanrıkulu'nun işten el çektirilmesi ve genel müdür Yalçın Davran'ın istifası nedeniyle eserin kayboluşu araştırılmaz.

2005 yılında Cemal Reşid Rey’in öğrencisi Dr. Aydın Karlıbel, Çelebìnin şef partisyonunun Ankara Devlet Opera ve Balesinde bulunduğunu tespit eder, izinle İstanbul'a getirir. Üzerinde altı ay kadar çalışarak, eksik olan 3. ve 4. perdenin nefesli sazlar partilerini tamamlar. 2014 yilında da 430 sayfadan oluşan Çelebinin komple piyano-şan partisyonunu hazırlar. El yazması şef partisyonunun dijital ortama aktarılmasını sağlar. 2006 yılında Dr. Aydın Karlıbel'in çabalarryla, Zeibek (Zeybek) ve Faire Sans Dire (Söylemeden Yapmak) operaları İstanbul Devlet Opera ve Balesi tarafından satın alınır.

Ekrem Reşid Rey ve Cemal Reşid Rey hayattayken operalarının temsil edildiğini görememiştir. Bu operalardan bugüne kadar sadece Çelebi operası 2010 yılında konser şeklinde icra edilmiş, sahneye konmamıştır.

Bu çalışmada; Türk opera literatürüne ve arşiv çalışmalarına katkıda bulunmak, Ekrem Reşid ve Cemal Reşid Rey gibi uluslararası düzeyde sanatçılarımızın eserlerinin kurumlarımızca seslendirilmesine teşvik amaçlanmıştır.

\section{Kaynaklar}

Ali, Filiz (1996). Cemal Reşid Rey’e Armă̆an. Ankara: Sevda Cenap And Müzik Vakfi Yay.

Andak, Selmi (1969). "Ölümünün 10.Yılında Cemal Reşid Rey Ağabeyi Ekrem Reşid'i Anlatıyor”. Cumburiyet Gazetesi. 13 Temmuz. 6.

Bozok, Hüsamettin (1950). "Ekrem Reşid Rey". Yeditepe Dergisi 11: 12.

Gazimihal, Mahmut Ragıb (2006). Anadolu Türküleri ve Musiki İstikbalimiz. İstanbul: Ötüken Yay.

İstanbul Devlet Opera ve Balesi (2011). İstanbul Devlet Opera ve Balesi Program 
Dergisi (2010-2011 Sezonu). İstanbul: İstanbul Devlet Opera ve Balesi Yay. İlyasoğlu, Evin (2005). Müzikten İbaret Bir Dünyada Gezintiler Cemal Reşid Rey. İstanbul: Dünya Yay.

İlyasoğlu, Evin (2007). 71 Türk Bestecisi. İstanbul: Pan Yay.

Karlıbel, Aydin (2008a). The Emergence of Cemal Reşid Rey's Çelebi and The Opera's Restoration: A Critical Study. Doktora Tezi. İstanbul: İstanbul Teknik Üniversitesi.

Karlıbel, Aydın (2008b). "Cemal Reşid Rey'in Çelebi Operasının Günışığına Çıkarılışı ve Restorasyonu: Bir Kritik İnceleme”. İstanbul Teknik Üniversitesi Dergisi 2: 69-76.

Karlıbel, Aydın (2009). “Cemal Reşid Rey’in Operaları I-II”. Orkestra Dergisi 407: 19-23.

Karlıbel, Aydın (2015). "Cemal Reşid Rey’in Çelebi Operasının Günışığına Çıkarılışı ve Restorasyonu”. Akdeniz Opera ve Bale Kulübü Kültür ve Sanat Dergisi 33: 41-42.

Necatigil, Behçet (2000). Edebiyatımızda İsimler Sözlüğü. İstanbul: Varlık Yay.

Polat, Nâzım H. (2003). "II. Meşrutiyet Devri Türk Kültür-Edebiyat ve Basın Hayatının Bir Yansıtıcısı Olarak Rübap Dergisi”. TÜBAR (Türklük Bilimi Araştırmaları) XIV (Güz): 7-41.

Tuncay, Murat (2010). "Cemal Reşid Rey ile Yayınlanması 37 Yıl Geciken Görüşme Notları". Yedi 3: 44-47.

Tura, Yalçın (2009a). “Cemal Reşid'in Operaları: Sultan Cem”. Orkestra Dergisi 401: 2-10.

Tura, Yalçın (2009b). “Cemal Reşid'in Operaları: L’Enchantement” (Büyülenme). Orkestra Dergisi 403: 3-7.

Tura, Yalçın (2009c). "Cemal Reşid'in Operaları: Köyde Bir Facia”. Orkestra Dergisi 406: 3-6.

Uçarsu, Hasan (2004). “Cemal Reşid Rey’in İlk Dönem Üretiminde Doğu-Batı İkilemi”. Mimar Sinan Güzel Sanatlar Üniversitesi Dergisi 2: 68-78. 


\title{
Operas of Ekrem Resid Rey and Cemal Resid Rey*
}

\author{
Elif Sanem Güleç* \\ İbrahim Şevket Güleç**
}

\begin{abstract}
The lives of Ekrem Reşid Rey (10 October 1900-13 July 1959) and Cemal Reşid Rey (25 October 1904-7 October 1985) symbolize the transition from Ottoman Empire to Republic of Turkey. Cemal Reşid Rey is the first representative of Turkish Five (five composers who pioneered western classical music in Turkey) and he usually worked with his brother Ekrem Reşid Rey on stage works. Operetta long existed in urban culture of Ottoman Empire and Rey brothers represented it in Republic Era. While these operettas were highly appraised, operas couldn't gain popularity. There is little information about those operas. In this article, seven operas of Rey brothers; La Femme Fugitive, Faire Sans Dire, Sultan Cem, L'Enchantement, Zeibek, Drame Anatolien and Çelebi will be studied. This study aims to contribute to Turkish opera literature and State Opera and Ballet archive.
\end{abstract}

\section{Keywords}

Ekrem Reşid Rey, Cemal Reşid Rey, Ottoman Empire, Republican period, opera, operetta.

\footnotetext{
* Date of Arrival: 12 August 2016 - Date of Acceptance: 14 March 2017

You can refer to this article as follows:

Güleç, Elif Sanem ve İbrahim Şevket Güleç (2020). “Ekrem Reşid Rey ve Cemal Reşid Rey Operaları”. bilig - Journal of Social Sciences of the Turkic World 93: 53-84.

** Asst. Prof. Dr., Kocaeli University, Faculty of Fine Arts, Department of Music - Kocaeli/Turkey ORCID ID: 0000-0002-9288-3255

elifsanem@gmail.com

${ }^{* * *}$ Res. Asst., Necmettin Erbakan University, State Conservatory of Turkish Music, Departmen of Music - Konya/Turkey ORCID ID: 0000-0002-7961-5715

isg7734@gmail.com
} 


\title{
Оперы Экрема Решид Рея и Джемаля Решид Рея*
}

\author{
Элиф Санем Гюлеч* \\ Ибрагим Шевкет Гюлеч
}

\begin{abstract}
Аннотация
Жизнь Экрема Решид Рея (10 октября 1900 -13 июля 1959) и Джемаля Решид Рея (25 октября 1904 - 7 октября 1985) символизирует переход от Османской империи к Турецкой Республике. Джемаль Решид Рей является первым представителем «Турецкой пятерки» (пять композиторов, ставших пионерами западной классической музыки в Турции), и он обычно работал со своим братом Экремом Решидом Реем над сценическими постановками. Оперетта долгое время существовала в городской культуре Османской империи, а братья Рей представляли ее в эпоху Республики. в то время как эти оперетты были высоко оценены обществом, оперы не могли завоевать популярность. Об этих операх сохранилось очень мало информации. В этой статье будут проанализированы семь опер братьев Рей: «La Femme Fugitive», «Faire Sans Dire», «Султан Джем», «L'Enchantement», «Зейбек», «Анатолийская драма» и «Челеби» Цель этого исследования - внести вклад в турецкую оперную литературу и государственный архив оперы и балета.
\end{abstract}

Ключевые слова

Экрем Решид Рей, Джемаль Решид Рей, Османская империя, Республиканский период, опера, оперетта.

\footnotetext{
* Поступило в редакцию: 12 августа 2016 г. - Принято в редакцию: 14 марта 2017 г.

Ссылка на статью:

Güleç, Elif Sanem ve İbrahim Şevket Güleç (2020). "Ekrem Reşid Rey ve Cemal Reşid Rey Operalar1”. bilig - Журнал Гуманитарных Наук Тюркского Мира 93: 53-84.

** д-р, Университет Коджаэли, Факультет изобразительных искусств, кафедра музыки -Коджаэли/ Турция ORCID ID: 0000-0002-9288-3255

elifsanem@gmail.com

**** Научный сотрудник, Университет им. Неджметтина Эрбакана, Государственная консерватория турецкой музыки, музыкальный факультет - Конья/Турция ORCID ID: 0000-0002-7961-5715

isg7734@gmail.com
} 